\title{
Isolated Relapse in the Oral Cavity of a Child with T-lineage Acute Lymphoblastic Leukemia
}

\author{
Andréa Conceição BRITO ${ }^{1}$ \\ Hermínia Marques CAPISTRANO ${ }^{2}$ \\ Mayara Louise TORRES ${ }^{2}$ \\ Gilberto RAMOS ${ }^{1}$ \\ Marcos Borato VIANA ${ }^{3}$ \\ Benigna Maria de OLIVEIRA ${ }^{3}$
}

\begin{abstract}
${ }^{1}$ Hematology Division, Clinics Hospital, UFMG - Federal University of Minas Gerais, Belo Horizonte, MG, Brazil ${ }^{2}$ Department of Dentistry, PUC/MG - Pontifical Catholic University of Minas Gerais, Belo Horizonte, MG, Brazil ${ }^{3}$ Department of Pediatrics, UFMG - Federal University of Minas Gerais, Belo Horizonte, MG, Brazil
\end{abstract}

\begin{abstract}
Despite high cure rates, approximately $20 \%$ of patients with acute lymphoblastic leukemia (ALL) have disease relapse. Isolated recurrence in oral cavity is extremely unusual. The aim of this paper is to report a case of an isolated relapse occurred in a child with T-lineage ALL. Clinical picture included swelling and pain in the right upper gingiva of the oral cavity, with no other clinical or hematological alterations. Diagnosis was confirmed by biopsy and immunohistochemical staining. Bone marrow aspiration was normal. Five months later leukemic infiltration of the bone marrow was detected and systemic chemotherapy was reintroduced. This case report highlights the relevance of dental care during and after chemotherapy, not only to treat lesions in the oral cavity resulting from the disease itself or from treatment side effects, but also to detect unusual sites of ALL relapse.
\end{abstract}

Key Words: lymphoid leukemia, relapse, gingival tissues.

\section{INTRODUCTION}

Acute leukemias are the most common malignancy in childhood. They represent approximately $30 \%$ of malignant diseases in patients under the age of 15 years. Acute lymphoblastic leukemia (ALL) is the most frequent type of leukemia in children (1-3).

Leukemia etiology remains unknown and seems to involve both genetic mechanisms and environmental factors. Its clonal origin is well established. Disorganized proliferation of a single progenitor cell disturbs hematopoiesis $(2,3)$. Clinical manifestations are due to the inhibition of hematopoiesis by leukemic cells and to leukemic infiltration in several organs and systems. Anemia, secondary to decreased red blood cell production, bleeding due to thrombocytopenia and infections due to neutropenia are the cardinal manifestations. Infiltration of organs results in hepatomegaly, splenomegaly and lymphadenopathy.
Leukemic infiltration in the central nervous system (CNS) and testes are also common events.

ALL diagnosis is confirmed when more than $25 \%$ of leukemic cells are detected in bone marrow aspiration. Immunophenotyping, molecular and cytogenetic tests are useful to characterize the leukemic cells and also have prognostic value (1). ALL treatment involves long-term chemotherapy, which has in the last decades undergone striking advances, leading to the current mark of around $80 \%$ of children and adolescents with ALL achieving cure (3). Despite these high cure rates, approximately $20 \%$ still have disease relapse (3), with bone marrow as the most frequent site, followed by the CNS (3-5). Nevertheless, relapse can occur in any tissue or organ.

Isolated recurrence in the oral cavity is extremely uncommon in ALL. Few case reports were found in a literature review, mostly in adolescents or adult patients who had histologically proven lesions in the oral cavity months or years after the end of the leukemia treatment.

Correspondence: Benigna Maria de Oliveira, Departamento de Pediatria, Faculdade de Medicina, UFMG, Avenida Alfredo Balena, 190, sala 267, 30130-100 Belo Horizonte, MG, Brasil. Tel: +55-31-3409-9772. Fax: +55-31-3409-9397. e-mail: benigna@uol.com.br 
Most patients had concomitant bone marrow relapse or had marrow infiltration detected shortly after the oral cavity relapse (6-9).

The purposes of this paper are to report a case of isolated recurrence in the oral cavity of a child with T-lineage ALL and highlight the relevance of dental care during and after chemotherapy for ALL.

\section{CASE REPORT}

A 4-year-old male child was first diagnosed with T-lineage ALL and treated according to the protocol of the Brazilian Group for Leukemia Treatment in Childhood ALL-99 (GBTLI-LLA99) for patients with high-risk for recurrence (10), relapsing at the age of 8 . At diagnosis karyotyping of bone marrow (BM) cells showed no metaphases for analysis. Dental monitoring was done during the whole treatment.

One year and four months after the end of the treatment, the child had swelling and pain in the oral cavity, in the right maxilla, with no other clinical or hematological signs or symptoms. The extraoral evaluation revealed swelling on the middle third of the right side of the face, with no signs of inflammation, causing facial asymmetry. Oroscopy showed swelling in the vestibular region of the primary maxillary right first and second molars and the permanent maxillary right first molar. The swelling extended further anteriorly into the palatal mucosa. The involved teeth had abnormal mobility and no caries. The swelling was firm and painful upon palpation and was covered by intact mucosa. Panoramic radiograph image showed radiolucent area involving an unerupted tooth and the presence of radiodensity on the right maxillary sinus (Fig. 1).

An incisional biopsy of the lesion was performed. The histological diagnosis confirmed oral mucosa infiltration by lymphoid precursor neoplastic T-cells. Histochemically they were positive for BCL-2, cytoplasmatic CD3 (polyclonal), CD45/LCA, CD99, and irregularly positive for TDT (polyclonal). Bone marrow aspiration and cerebrospinal fluid examination did not show evidence of leukemia infiltration. Computed tomographs of chest, sinuses, neck, abdomen, and pelvis were all negative for other organ infiltration. Gingival lesion spontaneously remitted soon after biopsy. Watchful waiting (no treatment) was adopted in view of the spontaneous regression and no signs of infiltration in other organs and systems.

Five months after the initial manifestation in the oral cavity, mild leukopenia and neutropenia were detected, without any other clinical or laboratory manifestations. Bone marrow aspiration showed infiltration by lymphoblasts with T-immunophenotype. Karyotype of bone marrow cells was 46, XY, t (10; 11) (p11; q13) [14]/46, XY [16]. No CNS infiltration was detected. Relapse treatment was started according to the GBTLI-LLA 2009 chemotherapy protocol for T-immunophenotype ALL. The child has been in remission now for 25 months, with no changes in the oral cavity. He is scheduled to receive additional maintenance therapy in up to 34 months. An HLAmatched donor has not been identified yet for eventual bone marrow transplantation. Regular dental follow-up has been maintained.

\section{DISCUSSION}

Dental monitoring of patients with leukemia during and after treatment is extremely relevant for early detection and appropriate treatment of diseaserelated lesions and side effects of chemotherapy $(6,11)$. The oral cavity in leukemia is prone to complications 


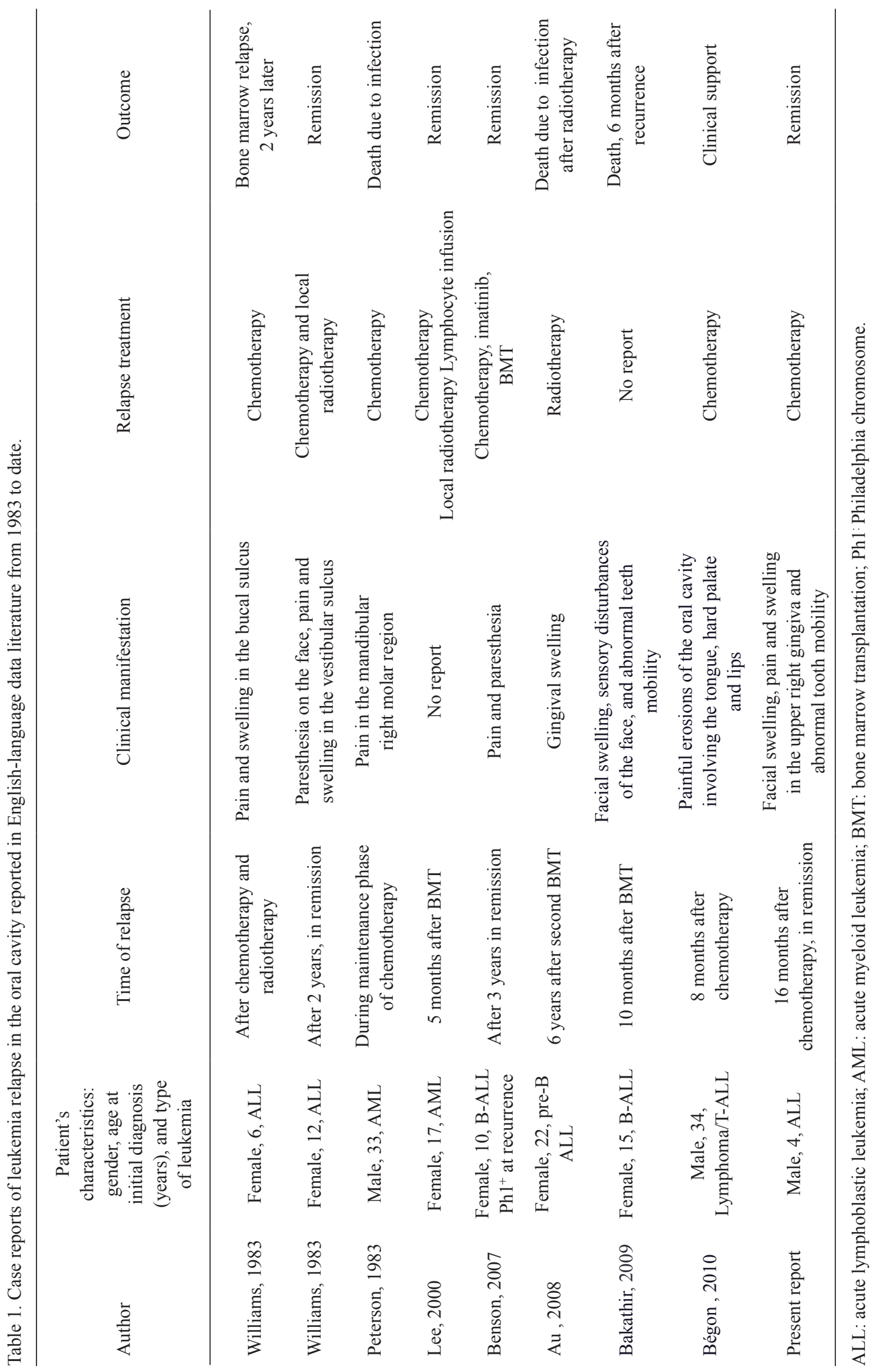


ranging from exacerbation of pre-existing pathological conditions to new mucosal lesions and infections (11-13).

Lesions resulting from infiltration of oral tissues by leukemia cells may occur in the gingival tissues or less frequently in the alveolar bones. These are less common in ALL than in the myeloid subtypes (14).

Isolated relapses of ALL are rare in the oral cavity (Table 1). Clinical and radiological characteristics are manifold $(6-9,15)$. Differential diagnosis includes infections and other malignancies $(7,16)$. While biopsy and immunohistochemical study are mandatory, microbiological tests can be useful in many cases (7).

Very few relapses of ALL in the oral cavity of children have been reported $(16,17)$. Most cases refer to adolescents and adult patients (Table 1). Nonspecific clinical manifestations - swelling and pain in the gingiva - were detected in the present report. Evaluation by an oral and maxillofacial surgeon, lesion biopsy, and immunohistochemical study were essential for the correct diagnosis, as also reported by many authors.

Relapse treatment can be done with combined chemotherapy, radiotherapy or bone marrow transplantation (BMT), whether autologous or allogeneic. Treatment results are usually unsatisfactory, since most institutions do not have standard treatment protocols for this type of relapse and the best therapy has not yet been defined. The option should take into consideration the prognostic factors for survival of children with relapse $(4,5,18)$. The patient referred to in this report had unfavorable prognostic factors such as bone marrow infiltration and T-immunophenotype. Children with isolated extramedullar relapse usually have a better prognosis than those with medullar involvement and patients with T-ALL had unfavorable outcome in several studies (5). Many papers demonstrated that the duration of the first remission is the most significant variable to influence an event-free survival. Children with late relapses have better prognosis than those with early recurrences. The reported case can be classified as of late recurrence, since it occurred three years after the initial diagnosis $(4,5,18)$.

Spontaneous local remission and absence of infiltration in other organs led to the initial approach of "watchful waiting". As in most of the reported cases (6-9), bone marrow infiltration occurred shortly after relapse in the oral cavity. Systemic chemotherapy was chosen, so far with favorable results.

In summary, even considering that ALL is curable in about $80 \%$ of the children, the challenge remains in trying to avoid relapses and in treating the relapsed child. As shown in the literature, new recurrences are the main obstacle for curing a significant number of patients. Isolated relapses in the oral cavity are rare and may precede bone marrow infiltration. Dental monitoring and investigation of lesions in this region are extremely relevant for an integral approach to the child with ALL and for early detection of disease relapse.

\section{RESUMO}

Apesar dos altos índices de cura, cerca de $20 \%$ dos pacientes com leucemia linfóide aguda (LLA) apresentam recidiva da doença. Recidiva isolada na cavidade oral é extremamente incomum. O objetivo deste trabalho é relatar um caso de recidiva isolada em criança com LLA de linhagem T. A apresentação clínica foi quadro de edema e dor na cavidade oral, na região superior da gengiva à direita, sem outras alterações clínicas ou hematológicas. O diagnóstico foi confirmado por meio de biópsia e imunohistoquímica. O mielograma era normal. Cinco meses após a manifestação inicial na cavidade oral, foi detectada infiltração leucêmica na medula óssea. $\mathrm{O}$ tratamento com quimioterapia sistêmica foi reintroduzido. Este relato de caso ressalta a importância do acompanhamento clínico e odontológico durante e após o tratamento quimioterápico, não somente com o objetivo de tratar as alterações na cavidade oral decorrentes da própria doença ou dos efeitos adversos do tratamento, mas para que sejam detectadas apresentações incomuns de recidiva na LLA.

\section{REFERENCES}

1. Ziegler DS, Dalla Pozza L, Waters KD, Marshall GM. Advances in childhood leukemia: successful clinical-trials research leads to individualized therapy. Med J Aust 2005;182:78-81.

2. Pui CH, Schrappe M, Ribeiro RC, Niemeyer CM. Childhood and adolescent lymphoid and myeloid leukemia. Hematology Am Soc Hematol Educ Program 2004:118-145.

3. Pui CH, Robison LL, A Look T. Acute lymphoblastic leukemia. Lancet 2008;371:1030-1043.

4. Gaynon PS. Childhood acute lymphoblastic leukaemia and relapse. Br J Haematol 2005;131:579-587.

5. Uderzo C, Conter V, Dini G, Locatelli F, Miniero R, Tamaro P. Treatment of childhood acute lymphoblastic leukemia after the first relapse: curative strategies Haematologica 2001;86:1-7.

6. Bakathir AA, Al-Hamdani AS. Relapse of acute lymphoblastic leukemia in the jaw. Oral Surg Oral Med Oral Pathol Oral Radiol Endod 2009;107:e14-e16.

7. Au WY, Wong KY, Leung RYY, Tong ACK. Isolated gingival relapse of acute lymphoblastic leukemia after transplantation. J Oral Pathol Med 2008;37:249-251.

8. Bégon E, Blum L, Benramdane R, Leroux C, Pascal F, Lévy A, et al.. Oral manifestation of T-cell leukemia/lymphoma. Arch Dermatol 2010;146:804-805.

9. Peterson DE, Gerad H, Williams LT. An unusual instance of leukemic infiltrate diagnosis and management of periapical tooth involvement. Cancer 1983;51:1716-1719.

10. Scrideli CA, Assumpção JG, Ganazza MA, Araujo M, Toledo $\mathrm{SR}$, Lee MLM, et al.. A simplified minimal residual disease polymerase chain reaction method at early treatment points can 
stratify children with acute lymphoblastic leukemia into good and poor outcome groups. Haematologica 2009;94:781-789.

11. Carrillo C, Fava M, Vizeu H, Soares-Junior LA, Odone Filho V. Dental approach in the pediatric oncology patient: characteristics of the population treated at the dentistry unit in a Pediatric Oncology Brazilian Teaching Hospital. Clinics 2010;65:569-573

12. Declerck D, Vinckier F. Oral complications of leukemia. Quintessence Int 1988;19:575-583.

13. Soares AF, Aquino ARL, Carvalho CHP, Nonaka CFW, Almeida D, Pereira Pinto L. Frequency of oral mucositis and microbiological analysis in children with acute lymphoblastic leukemia treated with $0.12 \%$ chlorhexidine gluconate. Braz Dent J 2011;22:312316.

14. Abdullah BH, Yahya HI, Kummoona RK, Hilmi FA, Mirza KB Gingival fine needle aspiration cytology in acute leukemia. J Oral Path Med 2002;31:55-58.
15. Lee KH, Lee JH, Kim S, Lee JS, Kim SH, Kim WK. High frequency of extramedullary relapse of acute leukemia after allogenic bone marrow transplantation. Bone Marrow Transplant 2000;6:147-152.

16. Benson RE, Rood HD, North S, Loescher AR, Farthing PM, Payne M. Leukemic infiltration of the mandible in a young girl. Int J Paediatr Dent 2007;17:145-150.

17. Williams SA, Duggan MB, Bailey CC. Jaw involvement in acute lymphoblastic leukemia. Br Dent J 1983;155:164-166.

18. Raetz EA, Bhatla T. Where do we stand in the treatment of relapsed acute lymphoblastic leukemia? Hematology Am Soc Hematol Educ Program 2012; 2012:129-136.

Received May 22, 2012 Accepted August 15, 2012 